\title{
METODE MENGAJAR KREATIF DALAM MENCIPTAKAN PEMBELAJARAN YANG MENYENANGKAN
}

\author{
Sri Sunarti, M.Pd
}

Balai Diklat Keagamaan Palembang sribdk@gmail.com

\begin{abstract}
Abstrak
Mengajar merupakan kegiatan penyampaian informasi dan ilmu pengetahuan kepada peserta didik dalam proses pembelajaran. Pembelajaran yang dilakukan haruslah menarik dan menyenangkan agar peserta didik tidak bosan. Selain itu juga, pembelajaran di desain semenarik mungkin agar hasil belajar siswa baik dan tujuan pembelajaran tercapai. Banyak metode pembelajaran kreatif yang dapat digunakan dalam pembelajaran, seperti experiential learning, story telling, case study dan role playing. Dengan menggunakan metode yang kreatif dalam pembelajaran, maka suasana belajar akan lebih menyenangkan.
\end{abstract}

Kata Kunci: pembelajaran, metode, mengajar, kreatif

\begin{abstract}
Teaching is an activity of delivering information and knowledge to students in the learning process. Learning that is carried out must be interesting and fun so that students do not get bored. In addition, learning is designed as attractive as possible so that student learning outcomes are good and learning objectives are achieved. Many creative learning methods can be used in learning, such as experiential learning, story telling, case studies and role playing. By using creative methods in learning, the learning atmosphere will be more enjoyable.
\end{abstract}

Keywords: learning, method, teaching, creative

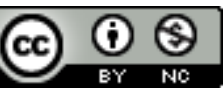

License

This work is licensed undera Creative Commons Attribution-NonCommercial 4.0 International 


\section{PENDAHULUAN}

Pembelajaran merupakan proses penyampaian materi dan informasi kepada siswa sehingga bertambahnya pengetahuan siswa. Untuk menciptakan suasana pembelajaran yang menyenangkan bukanlah hal mudah. Seperti yang tertuang dalam UndangUndang Nomor 20 Pasal 40 ayat 2 menjelaskan bahwa pendidik dan tenaga kependidikan berkewajiban menciptakan suasana pendidikan yang bermakna, menyenangkan, kreatif, dinamis dan dialogis. Selain itu juga, hal ini mengacu pada Peraturan Pemerintah Nomor 19 Pasal 19 Ayat 1 berbunyi: "Proses pembelajaran pada satuan pendidikan diselenggarakan secara interaktif, inspiratif, menyenangkan, menantang , memotivasi peserta didik untuk berpartisipasi aktif, memberikan ruang gerak yang cukup bagi prakarsa, kreatifitas dan kemadirian sesuai dengan bakat, minat dan perkembangan fisik serta psikologi peserta didik".

Menciptakan pola pembelajaran membutuhkan peran guru yang inovatif untuk membuat rancangan pembelajaran. Dengan kata lain, guru perlu menggunakan metode pembelajaran untuk tujuan agar siswa tidak cepat bosan dan bersemangat dalam belajar. Dalam pembelajara menciptakan kreatifitas yang dapat dilakukan dengan menerapkan berbagai metode.

Namun, pada kenyataannya, masih kita temukan pendidik yang mengajar dengan metode ceramah saja sehingga membuat suasana pembelajaran menjadi membosankan. Kurangnya kreatiftas mengajar pendidik karena pendidik masih belum membuka diri untuk membaca dan belajar hal-hal baru. Memang tidaklah mudah untuk menciptakan pembelajaran yang menyenangkan, perlu usaha dan kemauan untuk merubah kebiasaan. Oleh karena itu, tulisan ini membahas berbagai metode mengajar kreatif yang dapat menciptakan suasana belajar menjadi menyenan

\section{METODE PENELITIAN}

Penelitian ini merupakan penelitian yang bertujuan untuk mengembangkan metode mengajar kreatif dalam pembelajaran.Penelitian ini menggungkan. akan buku-buku (library search) dan literatur lainnya untuk menghasilkan informasi berupa catatan dan data deskriptif tentang materi. Oleh karena itu, metode penelitian yang digunakan dalam penelitian ini dinamakan metode studi pustaka.

Dengan metode ini dapat dikumpulkan datadata dan informasi yang dibutuhkan dan kemudian di lakukan klarifikasi dan deskripsi.

\section{TEMUAN DAN PEMBAHASAN}

\section{Temuan}

Dari hasil studi pustaka dan library reasearch maka ditemukan beberapa metode mengarjar kreatif sehingga dapat menciptakan pembelajaran menjadi aktif dan kreatif, yaitu metode experiential learning, metode story telling, metode case study dan metode role play. Keempat metode tersebut lebih mudah diterapkan dan dipahami oleh guru dalam menyampaikan materi. Selain itu, metodemetode ini lebih mudah dan sesuai dengan materi pelajaran yang akan disampaikan.

\section{Pembahasan}

\section{PRINSIP METODE MENGAJAR KREATIF}

Kreatif berarti kemampuan untuk memberikan berbagai alternatif jawaban berdasarkan informasi yang diberikan (Munandar, 2002). Sedangkan kreatifitas menurut Clark Monstakar dalam Utami Munandar menyatakan bahwa kreatifitas adalah

“ Pengalaman mengekspresikan dan mengaktualisasikan identitas individu dalam bentuk terpadu dalam hubungan dengan diri sendiri, dengan alam, dan dengan orang lain.

Kreatifitas dalam mengajar besar pengaruhnya dalam kemajuan pelaksanaan pendidikan apalagi mengajar, kreatifitas guru dalam melaksanakan tugas dapat memacu kemampuan untuk menghasilkan, merespon, mewujudkan ide, dan menanggapi berbagai permasalahan pendidikan yang muncul serta keberadaan guru yang kreatif memungkinkan peserta didik juga lebih kreatif lagi. 
Mengajar adalah kegiatan guru dalam mentransfer ilmu pengetahuan kepada peserta didik. Menurut Djamarah dan Zain (2010:39), "mengajar pada hakikatnya adalah suatu proses, yaitu proses mengatur, mengorganisasi lingkungan yang ada disekitar anak didik, sehingga dapat menumbuhkan dan mendorong anak didik melakukan proses belajar". Sedangkan Sudjana (Djamarah dan Zain, 2010) berpendapat bahwa mengajar adalah proses memberikan bimbingan/ bantuan pada anak didik dalam melakukan proses belajar. Sedangkan metode mengajar merupakan cara yang digunakan oleh guru untuk menyampaikan materi pelajaran kepada peserta didik agar lebih menarik dan mudah dipahami. Jadi, metode mengajar dapat diartikan sebagai cara yang dipergunakan oleh guru dalam mengadakan interaksi dan komunikasi dengan peserta didik pada saat berlangsungnya pengajaran.

Dari penjelasan diatas dapat didisimpulkan bahwa, metode mengajar kreatif adalah cara atau tahapan dengan berbagai teknik dan strategi kreatif yang digunakan oleh guru atau pendidik dalam proses pembelajaran sehingga pembelajaran menjadi menyenangkan dan tujuan pembelajaran dapat tercapai dengan baik.

Pemilihan metode mengajar yang tepat terkait dengan efektifitas pengajaran, ketepatan penggunaan metode mengajar dapat dipengaruhi oleh beberapa faktor, meliputi: (1)

Tujuan belajar yang hendak dicapai yaitu tingkah laku yang diharapkan dapat dinampakkan siswa setelah proses belajar mengajar, (2) Keadaaan peserta didik Keadaan pelajar berhubungan dengan kemampuan siswa untuk menangkap dan memperkembangkan bahan pengajaran yang diajarkan, (3) Bahan/materi pengajaran dalam menetapkan metode yang harus diperhatikan guru adalah bahan pengajaran, baik isi, sifat maupun cakupannya, (4) Situasi belajarmengajar Situasi belajar mengajar dapat digolongkan menjadi dua kelompok, yaitu situasi yang dapat diperhitungkan sebelumnya dan situasi yang tidak dapat diperhitungkan sebelumnya, (5) Fasilitas Fasilitas yaitu bahan atau alat bantu serta fasilitas yang lain yang bersifat fisik maupun non fisik dan (6) Setiapguru harus menyadari sepenuhnya tentang penguasaannya dalam menggunakan suatu metode yang sesuai dengan kepribadiannya.

\section{MACAM - MACAM MENGAJAR KREATIF}

METODE

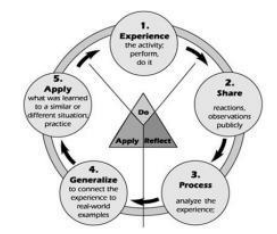

Dalam pembelajaran, ada beberapa metode mengajar kreatif yang dapat digunakan oleh guru, yaitu:

\section{1) Metode Mengajar Kreatif dengan Experiential Learning.}

Metode mengajar dengan Experiential Learning merupakan sebuah metode pembelajaran yang didasarkan pada teori Kolb, yaitu merupakan proses dimana pengetahuan terkonstruksi melalui transformasi pengalaman. Belajar dari pengalaman mencakup keterkaitan antara berbuat (the doing) dan berpikir (the thinking). Menurut Kolb \& Kolb (2005), tujuan teori pembelajaran konstruktivis sosial Vygotsky sejalan dengan pengembangan model pembelajaran Experiential. Seseorang akan belajar jauh lebih baik lewat keterlibatannya secara aktif dalam proses belajar.

Pembelajaran berbasis pengalaman menekankan akan kebutuhan lingkungan belajar dengan menyediakan kesempatan siswa belajar untuk mengembangkan dan membangun pengetahuan melalui pengalamannya. Pengalaman akan menyajikan dasar untuk melakukan refleksi dan observasi, mengkonseptualisasi dan menganalisis pengetahuan dalam pikiran anak.

Kolb (1994) mengemukakan 3 karakteristik model pembelajaran Experiential, yaitu a) belajar paling baik diterima sebagai suatu proses, di mana konsep diperoleh dan dimodifikasi dari kegiatan eksperimen, tidak dinyatakan dalam bentuk produk, b) belajar merupakan proses kontinu bertolak dari pengalaman, dan c) proses belajar memerlukan resolusi konflik.

Pembelajaran Experiential adalah proses belajar secara edukatif, berpusat pada pebelajar, dan berorientasi pada aktivitas serta direfleksikan secara personal tentang suatu pengalaman dan memformulasikan rencana untuk menetapkan apa yang telah diperoleh dari pengalaman sains yang menghasilkan pembelajaran yang berkualitas. Pengalamanpengalaman yang telah dialami siswa mempunyai peranan penting dalam 
pembentukan pengetahuan kognitif dalam pikiran siswa.Siswa merefleksikan pengalamannya pada sebuah pengetahuan baru. Keterlibatan siswa dalam kegiatan eksperimen akan membuat individu memperoleh pengalaman langsung yang konkrit.

Kolb menguraikan beberapa manfaat penerapan pembelajaran yang didasarkan pada pengalaman sebagai berikut (Adam, et al., 2004).

a) Menyediakan arah pembelajaran yang tepat dalam penerapan apa yang dipelajari.

b) Memberikan arah cakupan metode pembelajaran yang diperlukan.

c) Memberikan kaitan yang erat antara teori dan praktek.

d) Dengan jelas merumuskan pentingnya para siswa untuk merefleksikan dan merangsang siswa memberikan umpan balik tentang apa yang mereka pelajari.

e) Membantu dalam mengkombinasi gaya pengajaran sehingga pembelajaran menjadi lebih efektif.

Metode experiential learning memiliki empat siklus, yaitu concrete experiences atau pembelajaran yang didapatkan dari pengalaman nyata, reflection observation atau mengamati pengalaman yang dihadapi, abstract conceptualization atau memahami dan mencari informasi tentang apa yang diamati lalu membuat sebuah konsep atau teori dan experimentation atau membuat sebuah kesimpulan dari data-data yang diperoleh. Dengan belajar melalui pengalaman, siswa akan lebih paham dan bertpikir secara kritis sehingga dapat membangun pembelajaran yang menarik dan menyenangkan.

\section{2) Metode Mengajar Kreatif dengan Story Telling.}

Metode storytelling pada dasarnya merupakan metode yang menggunakan cerita dongeng untuk menggambarkan situasi yang terjadi dalam kehidupan sehari-hari yang dibantu dengan media pembelajaran salah satunya dengan media pembelajaran wayang atau story book. Istilah storytelling diterjemahkan dari bahasa Inggris Teaching English to Children menurut scott dan ytrebrg yaitu " storytelling digunakan dengan tidak menggunakan buku pada saat pembelajaran".
Storytelling digunakan dengan menuntut guru untuk bisa mengadaptasi dan menguasai isi pembelajaran yang terdapat dalam buku dengan cara menceritakannya kembali dalam bentuk dongeng. Setelah bercerita guru harus mengulang kembali kata kunci sehingga siswa menjadi faham dan mengerti.Selain itu, mimik dan ekspresi wajah dalam bercerita disesuaikan dengan objek yang diceritakan.Kemudian guru harus mampu mengajak siswa masuk ke dalam cerita tersbut menggunakan kontak mata antara guru dengan siswa pada waktu yang tepat. Sejalan dengan uraian tersebut, menurut Wright (2009) ketika guru melakukan storytelling, ada beberapa cara yang dapat digunakan untuk membantu pemahaman siswa yaitu:

a) Use the pictures, mask, objects and puppets. Hal ini bertujuan agar siswa dapat dengan mudah memhami suatu cerita yang sedang didengarkan. Ketika siswa tidak mengerti suatu kata yang diucapkan oleh guru, maka guru dapat menunjukan beberapa gambar yang ada dalam cerita, gambar tersebut bisa digambar oleh guru atu siswa itu sendiri di papan tulis, atau gambar-gambar yang ada pada buku. Guru juga dapat menggunakan topeng dan puppets untuk membantu pemahaman siswa, sama halnya dengan gambar, topeng dan puppets juga bisa dibuat oleh siswa itu sendiri.

b) Use mime your self, ketika guru bercerita guru dapat menirukan karakter tokoh-tokoh yang berada dalam cerita tersebut, seperti melakuk gerakan-gerakan, menirukan suarasuara binatang yang ada dalam cerita tersebut.

c) Use a sound effect. Agar pada saat bercerita tidak membosankan, maka guru dapat menggunakan berbagai macam efek suara seperti pada suara aslinya. Misalkan dalam cerita tersebur terdapat suara petir, disini guru harus dapat membuat suara yang sama seperti suara petir dll.

d) Translate key words as you tell the story, memberitahulan kata kunci kepada siswa dalam cerita tersebut, agar siswa dapat memiliki dan mengingat kosa kata yang baru.

Dalam menerapkan metode story telling, ada beberapa hal yang perlu diperhatikan yaitu seperti berikut: Orientation, Biasanya terletak di paragrap pertama. Secara teori, orientation berisi pesan tentang informasi WHAT, WHO, WHERE, DAN WHEN. Pada paragrap 
Orientation, text narative akan memberitahukan pembaca tentang apa peristiwanya siapa pelaku-pelakunya, dimana dan kapan peristiwa tersebut terjadi. Complication, Paragrap complication menjadi inti sebuah text narative. Complication ini menceritakan apa yang tejadi dengan pelaku dalam peristiwa tersebut. Umumnya Complication ini berisi gesekan antar pelaku peristiwa.Gesekan ini menimbulkan sebuah konplik/ pertentangan. Resolution, Sebuah pertentangan harus ditutup dengan penyelesaian.Dalam sebuah text narrative resolution bisa ditutup dengan penyelesaian yang menyenangkan atau menyedihkan.

Berdasarkan uraian di atas, metode storytelling merupakan salah satu metode yang memberikan kontribusi positif pada suatu pembelajaran, dapat yang memberikan pengalaman bagi siswa dalam pembelajaran sehingga pembelajaran akan lebih menyenangkan dan tidak membosankan dengan adanya materi yang berbentuk cerita, dengan didukung adanya aktivitas siswa salah satunya yaitu dengan melakukan percobaan yang melibatkan panca indera berhubungan dengan observasi, dan aktivitas lainnya berupa comunication dan inferensi.

\section{3) Metode Mengajar Kreatif dengan Case Study.}

Metode Student Created Case Studies merupakan salah satu metode pembelajaran aktif yang menggunakan tipe diskusi kasus atau permasalahan pelajaran yang akan dipelajari.

Menurut Liu (Nopitasari, 2012: 104) "Studi kasus adalah cara yang sangat tepat untuk mengeksplorasi kemungkinan efek pada pengajaran dan pembelajaran". Studi kasus berfokus pada persoalan yang ada dalam situasi atau contoh konkret, tindakan yang mesti diambil dan pelajaran yang bisa dipetik, serta cara-cara menangani atau menghindari situasi semacam itu di masa menatang (Silberman, 2016: 187).

Jadi metode Student Created Case Studies adalah metode pmbelajaran aktif yang memfokuskan siswa mengenai situasi nyata kasus atau contoh yang mengharuskan siswa untuk mengambil tindakan dan menyimpulkan manfaat yang dapat dipelajari.

Kegiatan pembelajaran melalui studi kasus atau pemecahan masalah merupakan suatu teknik yang dilakukan oleh guru untuk membantu siswa agar memahami dan menguasai materi pembelajaran.Selain itu, kegiatan pembelajaran melalui studi kasus dapat meningkatkan aktivitas dan kemandirian belajar siswa baik secara individu maupun kelompok.Menurut Surjadi (Dewi, 2013) "Tujuan pembelajaran studi kasus adalah untuk menganalisa dan memecahkan masalah yang dihadapi untuk mencapai kompetisi yang telah ditetapkan".Jadi, tujuan metode pembelajaran aktif Student Created Case Studies adalah sebagai berikut; Membantu siswa agar memahami dan menguasai materi pembelajaran, Meningkatkan aktivitas dan kemandirian belajar siswa, Menganalisa dan memecahkan masalah yang dihadapi untuk mencapai kompetisi yang ditetapkan.

Dari pengertian diatas, dapat disimpulkan bahwa metode Student Created Case Studies merupakan kerja siswa secara individual atau bekerja dalam kelompok kecil, yang ditekankan pada materi pelajaran yang mengandung persoalan untuk dipecahkan, siswa menggunakan banyak pendekatan dalam belajar dan hasil dari pemecahan masalah adalah hasil tukar pendapat di antara semua siswa.

\section{4) Metode Mengajar Kreatif dengan Role Play.}

Role playing adalah suatu cara penguasaan bahan-bahan pelajaran melalui pengembangan imajinasi dan penghayatan siswa yang di dalamnya terdapat aturan, tujuan, dan unsur senang dalam melakukan proses belajar mengajar (Santoso, 2011). Wikipedia (2012) juga mengemukakan bahwa role playing adalah sebuah permainan yang para pemainnya memainkan peran tokoh-tokoh khayalan dan berkolaborasi untuk merajut sebuah cerita bersama.

Hal ini diperkuat pendapat Hadari Nawawi dalam Kartini (2007) yang menyatakan bahwa bermain peran (role playing) adalah mendramatisasikan cara bertingkah laku orangorang tertentu dalam posisi yang membedakan peranan masing-masing dalam suatu organisasi atau kelompok di masyarakat.

Dari uraian diatas dapat disimpulkan bahwa model pembelajaran role playing adalah model pembelajaran inovatif yang dapat meningkatkan ketertarikan siswa terhadap materi pelajaran yang disajikan, sehingga tujuan pembelajaran lebih mudah tercapai. 


\section{LANGKAH-LANGKAH MENGAJAR KREATIF \\ 1) Experiential Learning.}

METODE

Dalam menerapkan metode experiential learning guru harus memperbaiki prosedur agar pembelajarannya berjalan dengan baik. Menurut Hamalik (dalam Fathurrohman 2015: 136-137), mengungkapkan beberapa hal yang harus diperhatikan dalam model pembelajaran experiential learning adalah sebagai berikut : (a) Gurumerumuskan secara saksama suatu rencana pengalaman belajar yang bersifat terbuka (open minded) mengenai hasil yang potensial atau memiliki seperangkap hasil-hasil tertentu. (b) Guru harus bisa memberikan rangsangan dan motivasi pengenalan terhadap pengalaman. (c) Siswa dapat bekerja secara individual atau bekerja dalam kelompokkelompok kecil atau keseluruhan kelompok di dalam belajar berdasarkan pengalaman. (d) Para siswa ditempatkan didalam situasi-situasi nyata pemecahan masalah. (e) Siswa aktif berpartisipasi didalam pengalaman yang tersedia, membuat keputusan sendiri, menerima konsekuensi berdasarkan keputusan tersebut. (f) Keseluruhan kelas menyajikan pengalaman yang telah dipelajari sehubung dengan mata ajaran tersebut untuk memperluas belajar dan pemahaman guru melaksanakan pertemuan yang membahas bermacam- macam pengalaman tersebut.

\section{2) Story Telling.}

Ada beberapa tahapan dalam Metode Story Telling, yaitu sebagai berikut :

a) Pra bercerita (before story). Pada tahap pra bercerita guru melakuan apersepsi terlebih dahulu tentang materi yang akan disampaikan yang dapat membangun konsepsi-konsepsi materi yang di pelajari. Hal tersebut dapat diaksanakan dengan menghadirkan permasalahan-permasalahan yang dekat dengan lingkungan siswa, pada akhirnya siswa merasa ingin tahu tentang jawaban atas pertanyaan yang mereka punya sehingga dapat meningkatkan minat siswa dalam belajar. Pada tahap bercerita terdapat tahapan yang lain yaitu tahap pengetahuan awal siswa. Tahap pengetahuan awal siswa ini mengharuskan guru untuk memberikan rangsangan kepada siswa atau dapat disebut juga dengan memberikan stimulus agar siswa memberikan respon positif terhadap mata pelajaran yang dipelajari siswa. Tahap pengetahuan awal siswa membantu siswa dalam mengingat apa yang diketahui siswa dan siswa pun dapat mengemukakan pendapatnya.

b) Bercerita (during story). Materi yang akan disampaikan berbentuk cerita dengan tokohtokoh pemainnya yaitu objek dalam materi sehingga objek tersebut dapat digunakan dalam sebuah percobaan. Melalui bercerita siswa dapat menyimak dan memahami isi materi yang disampaikan guru. Isi cerita terebut disesuaikan dengan tingkat perkembangan siswa.

Cerita tersebut di utarakan dengan bahasa yang jelas dan mudah dimengerti oleh siswa.Cerita disajikan dengan permasalahanpermasalahan yang sedang terjadi di lingkungan terdekat siswa dengan menumbuhkan karakter siswa.Pada tahap bercerita guru dituntut untuk dapat memfasilitasi siswa dalam mengeksplorasi pengetahuan yang dimilikinya.Adapun tahapan yang dimaksd adalah tahap eksplorasi.

Pada tahap ini siswa melakukan pengamatan atau percobaan yang berhubungan dengan materi yang sampaikan.Selain itu, siswa mencatat isi dari materi tersebut dan menghubungkannya dengan pengetahuan yang telah dimiliki siswa sebelumnya.Dalam tahap ini pula, siswa mengeksplor pengetahuan yang telah dimiliki siswa melalui LKS yang telah disediakan oleh guru.

c) Pasca bercerita (after story). Setelah mengeksplorasi kemampuan siswa dalam bentuk LKS. Selanjutnya siswa melakukan diskusi dengan kelompok yang telah ditentukan sebelumnya. Dalam diskusi ini siswa berkesempatan untuk mengutarakan pendapat dan menyamakan pendapatnya dengan kelompoknya. Selain itu, siswa dengan siswa lain dapat menyimpulkan pernyataan dari beberapa pendapat yang diutarakan oleh siswa lain dalam masingmasing kelompok.

Pengembangan dan aplikasi konsep Siswa menjawab pertanyaan-pertanyaan yang disampaikan guru secara lisan. Pertanyaanpertanyaan tersebut berhubungan materi yang diajarkan dan yang terdapat dalam LKS dengan memberikan pendapat siswa yang mampu mengomunikasikan kepada siswa lain untuk kemudian diarahkan 
kembali oleh guru untuk menyamakan persepsi.

3) Case Study.

Sintaks atau langkah-langkah model pembelajaran aktif (Active Learning) adalah sebagai berikut:

a) Menyampaikan tujuan dan motivasi siswa. Dalam fase ini guru menyampaikan semua tujuan pelajaran yang ingin dicapai pada pelajaran tersebut dan memotivasi siswa.

b) Menyajikan informasi. Dalam fase ini guru menyampaikan penjelasan umum tentang sistem pencernaan kepada siswa.

c) Mengorganisasikan siswa ke dalam kelompok. Dalam fase ini guru membagi siswa menjadi beberapa kelompok dengan cara berhitung dari 1-5 sampai membentuk 7 kelompok.

d) Membimbing kelompok bekerja dan belajar. Dalam fase ini guru membimbing kelompok-kelompok belajar pada saat mereka mengerjakan tugas mereka.

d) Memberikan penjelasan tentang kompetensi yang ingin dicapai.

e) Memanggil para siswa yang sudah ditunjuk untuk melakonkan skenario yang sudah dipersiapkan.

f) Masing-masing siswa berada di kelompoknya sambil mengamati skenario yang sedang diperagakan.

g) Setelah selesai ditampilkan, masingmasing siswa diberi lembar kerja untuk membahas penampilan yang selesai diperagakan.

h) Masing - masing kelompok menyampaikan hasil kesimpulannya.

i) Guru memberi kesimpulan secara umum.

j) Evaluasi

k) Penutup

\section{PENUTUP}

\section{Simpulan}

Metode mengajar kreatif menghasilkan pembelajaran yang menarik dan menyenangkan. Peserta didik dapat lebih mudah dan berani dalam mengungkapkan ide dan pendapatnya. Pendidik harus sebisa mungkin mendesain pembelajaran semenarik mungkin sehingga siswa lebih antusias dan termotivasi dalam belajar yang berdampak pada hasil belajar siswa. e) Evaluasi dan Refleksi. Dalam fase ini guru meminta siswa mempresentasikan hasil diskusi, guru mengevaluasi hasil belajar tentang materi yang telah dipelajari dengan memberikan soal dan penjelasan.

f) Memberikan penghargaan. Dalam fase ini guru memberikan penghargaan bagi kelompok yang terbaik sesuai dengan kriteria guru.

\section{4) Role Play.}

Setiap model pembelajaran aktif, ada beberapa langkah-langkah yang harus dilakukan. Berikut langkah-langkah penerapan model role playing menurut Mulyadi (2011:136) :

a) Guru menyiapkan skenario yang akan ditampilkan.

b) Menunjuk beberapa siswa untuk mempelajari skenario dalam waktu beberapa hari sebelum Kegiatan Belajar Mengajar.

c) Guru membentuk kelompok yang anggotanya lima orang (menyesuaikan jumlah siswa).

Dengan mendesain metode mengajar kreatif maka tujuan pembelajaran dapat tercapai dengan baik.

\section{Rekomendasi}

Berdasarkan dari kesimpulan diatas, maka penulis memberikan rekomendasi untuk:

1) Balai Diklat Keagamaan Palembang

Dapat melaksanakan pelatihan-pelatihan yang bersifat memberikan wawasan tentang berbagai metode mengajar kreatif sehingga guru-guru dapat menerapkan metode tersebut dalam pembelajaran

2) Guru

Dapat menambah wawasan guru dalam mengajar dan menerapkan metode tersebut dalam pembelajaran sehingga peserta didik menjadi lebih aktif dan kreatif.

3) Sekolah/Madrasah

Madrasah dapat memfasilitasi guru-guru dalam mengembangkan profesionalisme dalam mengajar sehingga dapat meningkatkan kualitas dan mutu Madrasah dalam pendidikan. 


\section{DAFTAR PUSTAKA}

Adam, A, B., Kayes, D, C., \& Kolb, D,A. 2004 experiential learning in teams. (online) http://www.learningfromexperience.com/research_library. Diakses tanggal 10 Juni 2020.

Dewi, A,S. 2010. Penerapan model role playing pada model role playing pada mata pelajaran IPS untuk meningkatkan aktivitas dan hasil belajar siswa kelas IV SDN Purwodadi 3 Kecamatan Blimbing kota Malang. Skripsi, Program S1 PGSD Jurusan Kependidikan Sekolah Dasar dan Prasekolah FIP Universtas Negeri Malang.

Djamarah, S. B., \& Zain, A. 2013. Strategi Belajar Mengajar. Jakarta: Rineka Cipta.

Djumingin, S. 2011. Strategi dan aplikasi model pembelajaran inovatif bahasa dan sastra.Makasar : Badan Penerbit UNM.

Fathurrohaman, M. 2015. Model-Model Pembelajaran Inovatif. Yogyakarta: Ar-Ruzz Media.

Kartini. 2007. Penggunaan metode role playing untuk meningkatkan minat siswa dalam pembelajaran pengetahuan sosial di kelas V sdn Cileunyi 1 Kecamatan Cileunyi Kabupaten 